\title{
Fate of Viable but Non-culturable Listeria monocytogenes in Pig Manure Microcosms
}

\author{
Jérémy Desneux ${ }^{1,2}$, Audrey Biscuit ${ }^{1,2}$, Sylvie Picard ${ }^{1,2}$ and Anne-Marie Pourcher ${ }^{1,2 *}$ \\ ${ }^{1}$ Irstea-Rennes, Rennes, France, ${ }^{2}$ Université Européenne de Bretagne, Rennes, France
}

OPEN ACCESS

Edited by:

Petr Kralik,

Veterinary Research Institute,

Czech Republic

Reviewed by:

Zhao Chen

Clemson University, USA

Silvana Vero,

Universidad de la Republica, Uruguay

*Correspondence:

Anne-Marie Pourcher

anne-marie.pourcher@irstea.fr

Specialty section:

This article was submitted to

Food Microbiology,

a section of the journal

Frontiers in Microbiology

Received: 16 December 2015

Accepted: 15 February 2016

Published: 02 March 2016

Citation:

Desneux J, Biscuit A, Picard S and Pourcher A-M (2016) Fate of Viable but Non-culturable Listeria monocytogenes in Pig Manure Microcosms. Front. Microbiol. 7:245. doi: 10.3389/fmicb.2016.00245
The fate of two strains of Listeria monocytogenes and their ability to become viable but non-culturable (VBNC) was investigated in microcosms containing piggery effluents (two raw manures and two biologically treated manures) stored for 2 months at 8 and $20^{\circ} \mathrm{C}$. Levels of $L$. monocytogenes were estimated using the culture method, qPCR, and propidium monoazide treatment combined with qPCR (qPCR ${ }_{P M A}$ ). The chemical composition and the microbial community structure of the manures were also analyzed. The strains showed similar decline rates and persisted up to 63 days. At day zero, the percentage of VBNC cells among viable cells was higher in raw manures (81.5-94.8\%) than in treated manures (67.8-79.2\%). The changes in their proportion over time depended on the temperature and on the type of effluent: the biggest increase was observed in treated manures at $20^{\circ} \mathrm{C}$ and the smallest increase in raw manures at $8^{\circ} \mathrm{C}$. The chemical parameters had no influence on the behavior of the strains, but decrease of the persistence of viable cells was associated with an increase in the microbial richness of the manures. This study demonstrated that storing manure altered the culturability of $L$. monocytogenes, which rapidly entered the VBNC state, and underlines the importance of including VBNC cells when estimating the persistence of the pathogens in farm effluents.

Keywords: L. monocytogenes, VBNC state, manure, microcosm, PMA, pyrosequencing

\section{INTRODUCTION}

The presence of Listeria monocytogenes, a food-borne pathogen, has been demonstrated in animal feces, manure and farm wastewaters (Farzan et al., 2010; Hellstrom et al., 2010; Boscher et al., 2012; Dungan et al., 2012; Pourcher et al., 2012). Humans can be exposed to L. monocytogenes strains by direct contact through farming operations or indirectly through consumption of food contaminated by manure from infected or shedding animals (Schlech et al., 1983; Nightingale et al., 2004; Mohammed et al., 2010). It has been reported that cattle farm ecosystems maintain a high prevalence of $L$. monocytogenes, including subtypes linked to human listeriosis (Nightingale et al., 2004). In a study conducted in piggeries in Brittany (France), Pourcher et al. (2012) observed high occurrence of L. monocytogenes in pig manures stored in pits and in lagoons after biological treatment (respectively, 18 and $24 \%$ of the samples were positive). Lyautey et al. (2007) showed a link between the occurrence of $L$. monocytogenes in surface waters in agricultural catchments in Ontario (Canada), the extent of cropped land and proximity to an upstream dairy operation. More recently, Stea et al. (2015), reported that surface waters may be a reservoir of L. monocytogenes, 
especially in rural agricultural watersheds. Farm environments may thus act as a vehicle for the dissemination of L. monocytogenes.

Several factors including temperature, moisture, $\mathrm{pH}$ and competition for nutrients may influence the survival of pathogenic bacteria (Guan and Holley, 2003). However, L. monocytogenes can acquire tolerance to numerous physical and physiochemical stresses and can thus survive in a wide range of environmental conditions (Roberts and Wiedmann, 2003; Gandhi and Chikindas, 2007), which may explain their high prevalence in stored and treated manures. Moreover, in response to environmental stress such as starvation, light, temperature, and $\mathrm{NaCl}$ concentrations, L. monocytogenes may become viable but non-culturable (VBNC; Besnard et al., 2002; Lindback et al., 2010). Although resuscitation from the VBNC state of L. monocytogenes is difficult to prove (Cappelier et al., 2007; Lindback et al., 2010), the presence of VBNC bacteria in the environment is a health risk for humans since the cells may retain their infectivity (Besnard et al., 2002).

In most studies on the survival of $L$. monocytogenes during manure storage, manure treatment (e.g., composting) or after manure is spread on soil, the viability of the pathogen was assessed only on the basis of its recovery by cultural methods (Nicholson et al., 2005; Grewal et al., 2007; Goberna et al., 2011; Erickson et al., 2014; Millner et al., 2014). Given the ability of L. monocytogenes to enter the VBNC state, the decrease in concentration reported by these authors may in fact underestimate the number of infectious pathogens. Very few studies have used molecular methods to quantify L. monocytogenes in urban or animal effluents. Wery et al. (2006) and Klein et al. (2011) investigated the persistence of L. monocytogenes inoculated in microcosms in sewage sludge and in cattle manure (stockpiled or composted), respectively, using cultural methods and qPCR targeting $h l y A$ gene. The results of these studies in which qPCR was used, showed a slower decline of L. monocytogenes cells than when a cultural method was used, suggesting the presence of non-culturable cells. However, DNA-based quantification methods detect DNA in both nonculturable and dead bacteria, leading to false positive results. To prevent the amplification of DNA from dead cells, propidium monoazide (PMA), a DNA-intercalating agent which can enter membrane-damaged cells, has been used in combination with qPCR (qPCR ${ }_{\mathrm{PMA}}$ ) to enable only viable bacteria to be quantified (Nocker et al., 2006; Adela Yanez et al., 2011; Contreras et al., 2011; Dong et al., 2014; Li et al., 2014; Forghani et al., 2015). However, it is worth noting that $\mathrm{qPCR}_{\mathrm{PMA}}$ remains difficult to apply in turbid matrices such as wastewater or manure containing high rates of suspended matter (Wagner et al., 2008; Varma et al., 2009). To overcome this drawback, our team has recently compared different experimental conditions to achieve optimal qPCR ${ }_{\text {PMA }}$ quantification of L. monocytogenes in pig manures (Desneux et al., 2015).

The aim of the present study was to evaluate the persistence of L. monocytogenes strains and their ability to enter the VBNC state during the storage of raw pig manure and biologically treated manure stored in a lagoon (lagoon effluent) at the laboratory scale at two temperatures $\left(8\right.$ and $\left.20^{\circ} \mathrm{C}\right)$ selected to mimic the average winter and summer temperatures in piggery lagoons in Brittany. Manure and lagoon effluent microcosms were inoculated with two rifampicin-resistant strains of L. monocytogenes originating from two piggeries, and quantified over a 63 days period by plate counts (cultivable cells), qPCR targeting hlyA gene (total cells) and qPCR after contact with PMA (viable cells). To better understand the relationship between the properties of the matrix and the behavior of L. monocytogenes, the chemical and microbial composition of the manures and the lagoon effluents were analyzed at T0 and after 2 months of incubation.

\section{MATERIALS AND METHODS}

\section{Bacterial Strains}

The experiments were carried out with two strains of L. monocytogenes: strain L111 (CIP 110869) and strain L120 (CIP 110870) isolated from pig manure and a lagoon effluent, respectively. The two strains were serotyped by the research unit Hygiene and Quality of Poultry and Pork Products (Anses Ploufragan, France). They belonged to serogroups IVb (L111) and IIb (L120). Two rifampicin-resistant (Rifr) mutants (L111r and L120r) were generated from the two selected strains as described in Lung et al. (2001) to facilitate L. monocytogenes enumeration on plate agar. The Rifr strains were cultivated at $37^{\circ} \mathrm{C}$ in nutritive broth (OXOID, France) supplemented with $3 \mathrm{~g} \mathrm{~L}^{-1}$ of glucose and $0.1 \mathrm{~g} \mathrm{~L}^{-1}$ of rifampicin (Sigma-Aldrich, France; NBG-RIF broth). Both strains had similar growth rates in the nutritive broth.

\section{Characteristics of the Treatment Processes}

Raw manures (Manures-1 and 2) and lagoon effluents (Lagoons1 and 2) were collected in sterile flasks from pig manure treatment processing units at two farms (farms 1 and 2) located in Brittany (France). The two manure treatment consists of prestorage of raw manure in a tank followed by centrifugation to remove phosphorus from the liquid phase. The recycled product (calcium or magnesium phosphate) is concentrated in a solid product mainly containing organic matter. The liquid phase is biologically treated in aerobic and anoxic stages in a reactor to reduce the level of nitrogen. The treated manure is dehydrated using a filter band press (farm 1) or settled in a settling tank (farm 2). The liquid fraction is then sent to an open-air lagoon where it is stored for 9-12 months before being used to water crops.

\section{Chemical Characterisation of Manure and Lagoon Effluent}

Total solids (TS), volatile solids (VS), total Kjeldahl nitrogen (TKN) and total ammonia nitrogen (TAN) were determined using standard methods (APHA, 1998). Volatile fatty acids (VFA) were analyzed using high-pressure liquid chromatography (HPLC; Peu et al., 2004). pH was measured using a hand-held $\mathrm{pH}$ meter (Hanna, Tanneries, France). 


\section{Preparation of the Microcosms}

Microcosm experiments were conducted in $200-\mathrm{mL}$ glass bottles containing $100 \mathrm{~mL}$ of raw manure or lagoon effluent. In order to simulate the storage condition of manure and lagoon, the bottles were closed with a screw plug to maintain anoxic conditions (raw manure microcosms) or with carded cotton plugs to allow air to penetrate (lagoon effluent microcosms). The bottles were stored for a week in the dark at $8^{\circ} \mathrm{C}$ or $20^{\circ} \mathrm{C}$ to enable acclimation of endogenous microbial flora before inoculation with $L$. monocytogenes strains.

A volume of $150 \mu \mathrm{L}$ of pure culture of the L111r or the L120r strain in the exponential phase growth in nutritive broth (Oxoid, France) was transferred into $100 \mathrm{~mL}$ NBG-RIF broth and incubated for $17 \mathrm{~h}$ at $37^{\circ} \mathrm{C}$ to obtain stationary-phase cells. Aliquots $(40 \mathrm{~mL})$ of the incubated NBG-RIF broth were centrifuged for $5 \mathrm{~min}$ at $5000 \mathrm{~g}$. The pelleted cells were suspended in $5 \mathrm{~mL}$ of $0.8 \% \mathrm{NaCl}$ and centrifuged for $5 \mathrm{~min}$ at $5000 \mathrm{~g}$. The pellet was resuspended in $5 \mathrm{~mL}$ of $0.8 \% \mathrm{NaCl}$. Next, each microcosm was inoculated with $1 \mathrm{~mL}$ of the bacterial suspension to reach an initial concentration of approximately $10^{8}$ L. monocytogenes $\mathrm{mL}^{-1}$. Three microcosms were used for each strain. A total of 24 microcosms (two strains, two raw manures, two lagoon effluents, three replicates) were stored in the dark at $20^{\circ} \mathrm{C}$ or $8^{\circ} \mathrm{C}$ for 63 days.

\section{Quantification of Autochthonous L. monocytogenes in Raw Manures and Lagoon Effluents}

Listeria monocytogenes was enumerated by a three-tube MPN method. Before inoculation with the Rifr strains, 10,1 , and $0.1 \mathrm{~mL}$ of raw manure or lagoon effluent were transferred in $90 \mathrm{~mL}$ or $9 \mathrm{~mL}$ of ONE Broth-Listeria (Oxoid, France). After incubation for $48 \mathrm{~h}$ at $30^{\circ} \mathrm{C}, 0.1 \mathrm{ml}$ of each enrichment broth was plated onto Rapid L'mono agar (Bio-Rad, France) and incubated for $48 \mathrm{~h}$ at $37^{\circ} \mathrm{C}$. Characteristic colonies of $L$. monocytogenes were identified based on their phosphatidylinositol phospholipase C (PIPLC) activity.

\section{Quantification of Rifr Strains in the Microcosms}

Samples for cultural, qPCR and qPCR PMA quantification were collected in each microcosm immediately after inoculation of the Rifr strains (T0), and after 7, 21, 42, and 63 days of incubation.

\section{Cultural Method}

Serial 10-fold dilutions were prepared in peptone water (Oxoid, France). A volume of $0.25 \mathrm{~mL}$ of undiluted matrices or $0.1 \mathrm{~mL}$ of dilutions was surface plated on PALCAM agar without supplement (Oxoid, France) containing $100 \mathrm{mg} \mathrm{L}^{-1}$ of rifampicin and $50 \mathrm{mg} \mathrm{L}^{-1}$ of cycloheximide (Sigma-Aldrich, France). Colonies were counted after $48-72 \mathrm{~h}$ of incubation at $37^{\circ} \mathrm{C}$. Results are expressed as $\mathrm{cfu} \mathrm{mL}^{-1}$. The limit of detection was $4 \mathrm{cfu} \mathrm{mL}^{-1}$.

\section{Propidium Monoazide (PMA) Treatment}

Propidium monoazide (Biotium, Inc., Hayward, CA, USA) was dissolved in water to prepare a stock solution $\left(1 \mathrm{mg} \mathrm{mL}^{-1}\right)$ stored in the dark at $-20^{\circ} \mathrm{C}$. PMA was used as described in Desneux et al. (2015). Briefly, $400 \mu \mathrm{L}$ of manure or $600 \mu \mathrm{L}$ of lagoon effluent were transferred in transparent polypropylene reaction tubes (Greiner Bio-One, France). PMA was added to the tubes containing manure or lagoon effluent at a final concentration of 55 or $20 \mu \mathrm{M}$, respectively. After incubation in the dark at room temperature for $5 \mathrm{~min}$ (manure) or $20 \mathrm{~min}$ (lagoon effluent), the samples were placed horizontally on ice at a distance of $20 \mathrm{~cm}$ from a $650-\mathrm{W}$ halogen light source. They were exposed to the light source for $55 \mathrm{~min}$ (manure) or $30 \mathrm{~min}$ (lagoon effluent). Then, $250 \mu \mathrm{L}$ of PMA treated manure and $500 \mu \mathrm{L}$ of PMA treated lagoon effluent were transferred in $2 \mathrm{~mL}$ tubes and centrifuged for $5 \mathrm{~min}$ at $5000 \mathrm{~g}$. The pellets were stored at $-20^{\circ} \mathrm{C}$ before DNA extraction.

\section{DNA Extraction and Quantification of L. monocytogenes and Total Bacteria}

DNA was extracted from PMA treated and untreated samples with Nucleospin kit for soil (Macherey Nagel) according to the manufacturer's instructions with one modification of the elution procedure as described in Desneux and Pourcher (2014).

Listeria monocytogenes were quantified using the protocol of Nogva et al. (2000). Briefly, PCR reactions were performed in a volume of $25 \mu \mathrm{L}$ containing $2 \mu \mathrm{L}$ of diluted DNA, 1X TaqMan Buffer, $5 \mathrm{mM} \mathrm{MgCl} 2,200 \mu \mathrm{M}$ dNTPs, $0.1 \mu \mathrm{M} \mathrm{L}$. monocytogenesspecific probe, $0.3 \mu \mathrm{M} L$. monocytogenes specific primers (LiMo) (each), $12.5 \mu \mathrm{L}$ of iQ Supermix (Bio-Rad, France) and water to complete the volume to $25 \mu \mathrm{L}$. Cycling parameters were $95^{\circ} \mathrm{C}$ for $10 \mathrm{~min}$, followed by $40 \mathrm{cycles}$ at $95^{\circ} \mathrm{C}$ for $20 \mathrm{~s}$ and $60^{\circ} \mathrm{C}$ for $60 \mathrm{~s}$.

For total bacteria, PCR reactions were performed in a volume of $25 \mu \mathrm{L}$ containing $12.5 \mu \mathrm{L}$ of iQ SYBR Green Supermix (BioRad, France), $200 \mathrm{nmol} \mathrm{L}^{-1}$ of each primer (W18 and W02), $2 \mu \mathrm{L}$ of diluted DNA, and $9.5 \mu \mathrm{L}$ of water. The cycling parameters were $95^{\circ} \mathrm{C}$ for $10 \mathrm{~min}$, followed by 45 cycles at $95^{\circ} \mathrm{C}$ for $30 \mathrm{~s}, 60^{\circ} \mathrm{C}$ for $50 \mathrm{~s}$, and $72^{\circ} \mathrm{C}$ for $30 \mathrm{~s}$.

The primers and probes used are listed in Table 1. The PCR reaction was prepared using the Automated Pipetting System epMotion ${ }^{\circledast}$ (Eppendorf, France). PCR amplification was performed using a Bio-Rad CFX96 real-time PCR machine with Bio-Rad CFX Manager software, version 1.1 (Bio-Rad, France). Data were processed with Opticon Monitor version 3. 1. 32 and CFX manager version 1. 1 (Biorad, Hercule, CA, USA).

Given that $h l y A$ is present as a single copy in the genome of L. monocytogenes (Mengaud et al., 1988), the results are expressed as cfu equivalent (cfu-eq). Dilutions ranged from $4.5 \times 10^{8}$ to $4.5 \mathrm{cfu}$-eq. Standard curves were generated by plotting threshold cycles $(\mathrm{Ct})$ against cfu-eq. The detection threshold was $5.10^{3} \mathrm{cfu}-$ eq $\mathrm{mL}^{-1}$ for manure and $2.5 .10^{3} \mathrm{cfu}$-eq $\mathrm{mL}^{-1}$ for lagoon effluent.

The cultural method and the qPCR performed on PMA treated samples and on untreated samples estimated:

- the culturable cells: plate counts

- the total number of cells: qPCR without PMA 
- the number of viable cells: $\mathrm{qPCR}_{\mathrm{PMA}}$

- the number of VBNC: [qPCRPMA] - [plate counts]

\section{T90 Calculations and Statistical Analysis}

According to the curve characteristics, decay rates were estimated as T90 values using Chick's model [monophasic model, $C_{(\mathrm{t})}=C_{0} \times e^{-\mathrm{kt}}$ ] or Cerf's model [biphasic model, $C_{(\mathrm{t})}=C_{0} \times\left(f \times e^{-\mathrm{k} 1 \mathrm{t}}+(1-\mathrm{f}) \times e^{-\mathrm{k} 2 \mathrm{t}}\right]$ described in Xiong et al. (1999). $C_{(\mathrm{t})}$ is the concentration at time t, $C_{0}$ is the initial concentration, $\mathrm{k}$ is the first order decay rate constant, $f$ is the initial proportion of the first fraction, $\mathrm{k} 1$ and $\mathrm{k} 2$ are the decay constants of the first and second phase, respectively. Decay rate models and their parameters were obtained using XLSTAT 2010 software. T90 (expressed in days) was calculated as follows: $\mathrm{T} 90=-\ln (0.1) / \mathrm{k}$ (Chick's model) or T $90=-\ln (0.1) / \mathrm{k} 1$ (Cerf's model). When the decay appeared after a lag, the T90 was calculated, taking into account the lag period. T90 were subjected to analysis of variance, and a Newman-Keuls test for multiple comparisons was applied to determine significantly different T90 $(p<0.05)$. Comparison of the $\log _{10}$ reduction and T90 of the two strains was analyzed by means of the Student's $t$-test $(p<0.01)$.

\section{Pyrosequencing of 16S rDNA Gene Sequences}

The microbial diversity of the manure and the lagoon effluent microcosms stored at 8 and $20^{\circ} \mathrm{C}$ was analyzed using a metagenomic approach applying 454-pyrosequencing technology. At T0 and T63, DNA extracted from the three replicate microcosms inoculated with strain L111r were pooled to obtain a total volume of $100 \mu \mathrm{L}$. DNA was precipitated with ethanol to reach a final volume of $20 \mu \mathrm{L}$. The $16 \mathrm{~S}$ rDNA V3-V4 region of DNA was amplified with the primers F343 (5'-CTTTC CCTACACGACGCTCTTCCGATCTTACGGRAGGCAGCAG$3^{\prime}$ ) and R784 (5'-GGAGTTCAGACGTGTGCTCTTCCGATCTT ACCAGGGTATCTAATCCT- $3^{\prime}$ ) using 30 amplification cycles with an annealing temperature of $65^{\circ} \mathrm{C}$. The average amplicon length was $510 \mathrm{bp}$. The $16 \mathrm{~S}$ rDNA V3-V4 region of the DNA extracts was sequenced on the GeT-PlaGe platform in Toulouse (Genotoul, Toulouse, France) using Illumina Miseq technology. Because MiSeq enables paired 250-bp reads, the ends of each read overlap and can be stitched together to generate extremely high quality, full-length reads of the entire V3 and V4 region in a single run. Single multiplexing was performed using a homemade $6 \mathrm{bp}$ index, which was added to the R784 during a second PCR with 12 cycles using forward primer (AATGATACGGCGACCACCGAGATCTACACTCTT TCCCTACACGAC) and reverse primer (CAAGCAGAAGA
CGGCATACGAGAT-index-GTGACTGGAGTTCAGACGTGT). The resulting PCR products were purified and loaded onto the Illumina MiSeq cartridge according to the manufacturer's instructions. The quality of the run was checked internally using PhiX, and then each paired-end sequence was assigned to its sample with the help of the previously integrated index.

\section{Analysis of Pyrosequencing Data Using the QIIME Pipeline}

The data were studied using the quantitative insights into microbial ecology (QIIME) pipeline (Caporaso et al., 2010b). Operational taxonomic units (OTUs) were formed at $97 \%$ similarity using UCLUST (Edgar, 2010). The representative sequences of each OTU were aligned to $16 \mathrm{~S}$ reference sequences using PyNAST with a minimum length of $150 \mathrm{bp}$ and $75 \%$ minimum percent identity (Caporaso et al., 2010a). The alpha diversity within the microcosm samples was estimated by the Chaol richness estimator, the abundance-based coverage (ACE) estimator and the Shannon index. Shifts in bacterial community structure over time were assessed by principal coordinate analysis (PCoA) of the pairwise weighted Unique Fraction (UniFrac) distances (Lozupone and Knight, 2005; Lozupone et al., 2006, 2011). Uncertainty in PCoA plots was estimated using jackknife analysis, in which the jackknife replicate was 10.

\section{RESULTS}

Autochthonous L. monocytogenes were not detected ( $<4$ MPN $100 \mathrm{~mL}^{-1}$ ) in the four matrices collected for the microcosm assays.

\section{Persistence of Inoculated Strains in Manures and Lagoons}

Figure 1 shows the levels of strains L111r and L120r for each culture and molecular method in the two manures stored at 8 and $20^{\circ} \mathrm{C}$. A decrease in the concentration of L. monocytogenes was observed in all microcosms but both strains were still recovered 63 days after the inoculation. The two strains displayed similar behavior depending on the temperature and on the origin of the manure (Figure 1, Supplementary Table S1). Generally, the lowest temperature increased the persistence of both strains, regardless of the quantification method used. The $\log _{10}$ reduction observed between 8 and $20^{\circ} \mathrm{C}$ was more marked using plate counts. The biggest difference was observed in Manure-2 microcosms in which the average reduction in culturable bacteria did not exceed $1.2 \log _{10}$ at $8^{\circ} \mathrm{C}$ whereas

TABLE 1 | Sequences of primers and probes used in the study.

\begin{tabular}{llcr}
\hline Probe and primers & Sequences $\left(\mathbf{5}^{\prime} \mathbf{-} \mathbf{3}^{\prime}\right)$ & Tm $\left.\mathbf{(}^{\circ} \mathbf{C}\right)$ & Reference \\
\hline LiMo F & TGC-AAG-TCC-TAA-GAC-GCC-A & 60.3 & Nogva et al., 2000 \\
LiMo R & CAC-TGC-ATC-TCC-GTG-GTA-TAC-TAA & 60.3 & Nogva et al., 2000 \\
Probe hlyA & CGA-TT-CAT-CCG-CGT-GTT-TCT-TT-CG & 70.2 & Nogva et al., 2000 \\
W18 & GAGTTGATCMTGGCTCAG & 50 & Godon et al., 1997 \\
W02 & GNTACCTTGTACGACTT & 50 & Weisburg et al., 1991
\end{tabular}



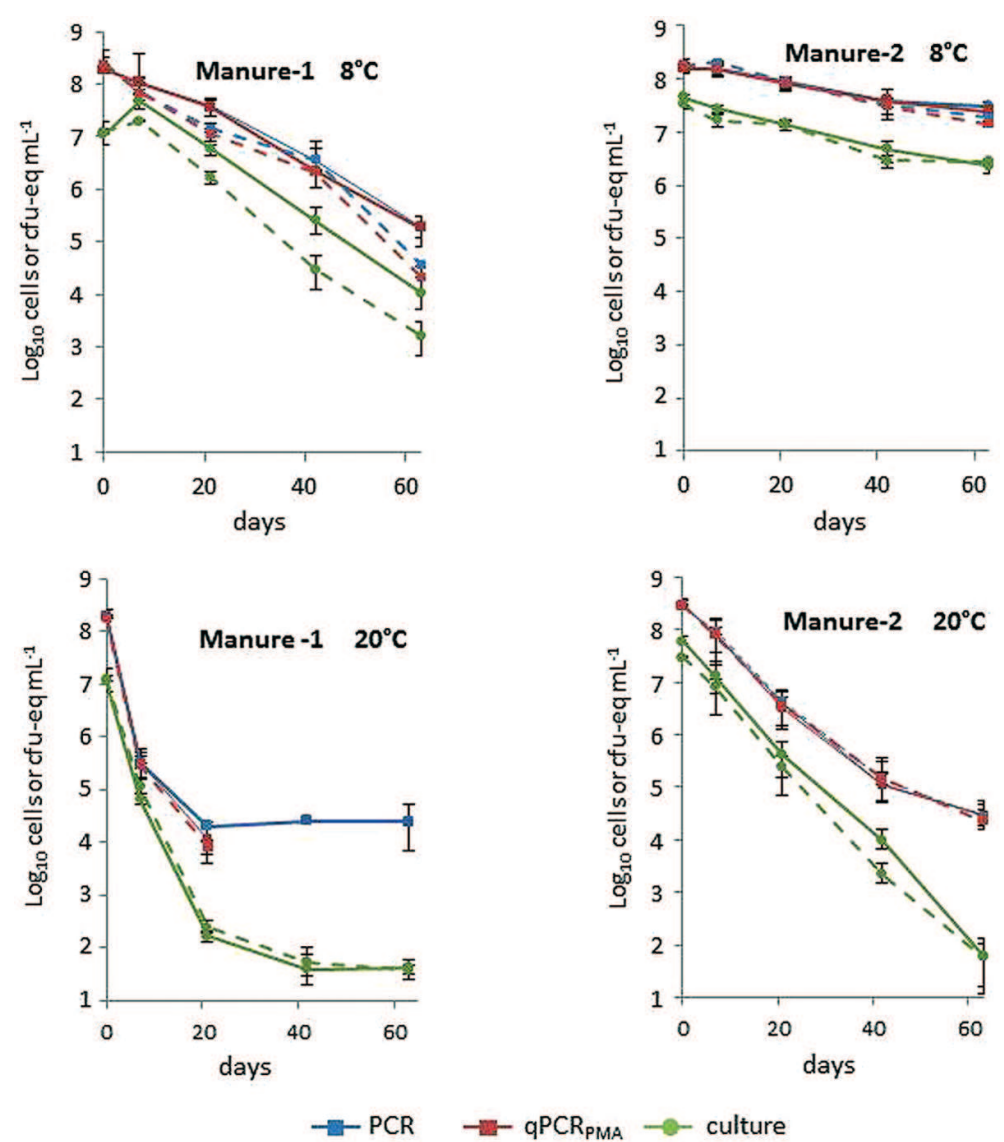

FIGURE 1 | Average concentrations of strains L111r (solid line) and L120r (dotted line) in Manure-1 and Manure-2 incubated at 8 and $20^{\circ} \mathrm{C}$ by qPCR,

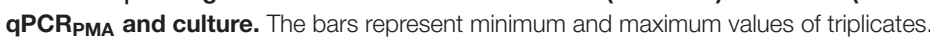

it reached $6.2 \log _{10}$ after 2 months of incubation at $20^{\circ} \mathrm{C}$ (Table 2). T90 values observed with both cultural and molecular methods were approximately 2.5 -fold lower in Manure- 1 than in Manure-2. Except for cultivable cells at $20^{\circ} \mathrm{C}$, the $\log _{10}$ reduction after 63 days was also higher in Manure- $1\left(3.4-3.8\right.$ at $8^{\circ} \mathrm{C} ; \geq 4.4$ at $\left.20^{\circ} \mathrm{C}\right)$ than in Manure-2 $\left(0.9-1.2\right.$ at $8^{\circ} \mathrm{C} ; 4.0$ at $\left.20^{\circ} \mathrm{C}\right)$. Moreover, the decrease in the concentration of both strains at $20^{\circ} \mathrm{C}$ showed a marked biphasic pattern in Manure-1, which was not observed in Manure-2, with a break in the kinetics after 21 days of incubation.

The two strains also exhibited similar behavior in the lagoon microcosms regardless of the method of quantification (Figure 2, Supplementary Table S1). The T90 values and the $\log _{10}$ reduction were affected by the origin and the temperature of the lagoon, but to a lesser extent than that observed in manure microcosm assays. At $8^{\circ} \mathrm{C}$, both strains persisted better in Lagoon-1 than in Lagoon-2 whereas the opposite was observed at $20^{\circ} \mathrm{C}$. Both strains persisted longer at $8^{\circ} \mathrm{C}$ in Lagoon-2 with a T90 of between 25.7 and 37.1 days at $8^{\circ} \mathrm{C}$, and between 10.1 and 12.2 days at $20^{\circ} \mathrm{C}$. The $\log _{10}$ reduction was also lower at $8^{\circ} \mathrm{C}$ (1.6-2.4) than at $20^{\circ} \mathrm{C}(4.3-5.9)$ after 2 months of incubation. In contrast, the persistence of the strains in Lagoon-1 was hardly influenced by the temperature, leading to a similar $\log _{10}$ reduction (approximately 3.1 ) at the end of the incubation period.

\section{Comparison of the Level of the Cultivable, Viable, and Total Bacteria}

Considering the strains together, there was no significant difference between the T90 values obtained with the cultural and molecular methods at $20^{\circ} \mathrm{C}(p>0.05)$, regardless of the matrix, whereas the $\log _{10}$ reduction was systematically significantly higher $(p<0.05)$ after 63 days when estimated using cultural method (Table 2). At $8^{\circ} \mathrm{C}$, the same trend was observed, but the differences between the $\log _{10}$ reductions were less marked than at $20^{\circ} \mathrm{C}$.

At T0, the difference in L. monocytogenes concentrations measured with the cultural method and with qPCR $\mathrm{PMA}$ ranged from 0.5 to $0.7 \log _{10}$ in the lagoon effluent microcosms and from 0.7 to $1.3 \log _{10}$ in the manure microcosms. Interestingly, the biggest differences in concentration obtained between culture and qPCR $\mathrm{PMA}$ were observed in Manure-1. Except for Manure1 at $8^{\circ} \mathrm{C}$, for which growth of cultivable bacteria was observed during the first week of incubation, cultivable, total and viable cells exhibited similar behavior during the 21 first days. After 3 weeks, in all microcosms at $20^{\circ} \mathrm{C}$ and in two microcosms at $8^{\circ} \mathrm{C}$, the levels of cultivable cells declined faster than viable bacteria, pointing to an increase in $\mathrm{VBNC}$ forms over time. 
TABLE 2 | T90 values (days) and $\log _{10}$ reduction after 63 days for the two strains of Listeria monocytogenes (mean of 6 values) in manure and lagoon effluent microcosms maintained at 8 and $20^{\circ} \mathrm{C}$.

\begin{tabular}{|c|c|c|c|c|c|c|c|c|c|}
\hline \multirow[t]{3}{*}{ Matrix } & \multirow[t]{3}{*}{ Method } & \multicolumn{4}{|c|}{ T90 (days) } & \multicolumn{4}{|c|}{$\log _{10}$ reduction } \\
\hline & & \multicolumn{2}{|c|}{$8^{\circ} \mathrm{C}$} & \multicolumn{2}{|c|}{$20^{\circ} \mathrm{C}$} & \multicolumn{2}{|c|}{$8^{\circ} \mathrm{C}$} & \multicolumn{2}{|c|}{$20^{\circ} \mathrm{C}$} \\
\hline & & Mean & (SD) & Mean & (SD) & Mean & (SD) & Mean & (SD) \\
\hline \multirow[t]{3}{*}{ Manure-1 } & Culture & $21.2^{\mathrm{e}}$ & $(1.7)$ & $3.6^{b}$ & $(0.6)$ & $3.5^{\mathrm{abc}}$ & $(0.6)$ & $5.5^{\mathrm{b}}$ & $(0.2)$ \\
\hline & qPCR & $19.3^{\text {ef }}$ & $(3.6)$ & $2.5^{\mathrm{b}}$ & $(0.2)$ & $3.4^{\mathrm{abc}}$ & $(0.4)$ & $4.4^{\mathrm{C}}$ & $(0.5)$ \\
\hline & qPCRPMA & $18.9^{\text {ef }}$ & $(5.9)$ & $2.5^{\mathrm{b}}$ & $(0.2)$ & $3.8^{a}$ & $(0.7)$ & $\geq 4.6^{\dagger}$ & \\
\hline \multirow[t]{3}{*}{ Manure-2 } & Culture & $53.5^{a}$ & $(4.9)$ & $9.9^{a}$ & $(1.5)$ & $1.2^{\mathrm{fg}}$ & $(0.2)$ & $6.2^{a}$ & $(0.5)$ \\
\hline & qPCR & $56.7^{\mathrm{a} *}$ & $(2.1)$ & $12.1^{\mathrm{a}}$ & $(1.1)$ & $0.9^{9}$ & $(0.1)$ & $4.0^{\mathrm{C}}$ & $(0.2)$ \\
\hline & qPCRPMA & $51.7^{\mathrm{a} *}$ & $(5.7)$ & $11.2^{\mathrm{a}}$ & $(1.1)$ & $1.1^{\mathrm{fg}}$ & $(0.1)$ & $4.0^{\mathrm{C}}$ & $(0.2)$ \\
\hline \multirow[t]{3}{*}{ Lagoon-1 } & Culture & $18.4^{\text {ef }}$ & $(3.6)$ & $10.3^{a}$ & $(2.8)$ & $3.6^{a b}$ & $(0.6)$ & $4.0^{c}$ & $(0.7)$ \\
\hline & qPCR & $17.1^{\text {ef }}$ & $(2.5)$ & $10.7^{a}$ & $(2.9)$ & $2.9^{c}$ & $(0.2)$ & $2.5^{d}$ & $(0.2)$ \\
\hline & qPCRPMA & $15.2^{f}$ & (3.3) & $10.0^{\mathrm{a}}$ & (3.3) & $3.2^{\mathrm{bc}}$ & $(0.2)$ & $2.8^{d}$ & $(0.2)$ \\
\hline \multirow[t]{3}{*}{ Lagoon-2 } & Culture & $25.7^{d}$ & $(0.5)$ & $10.6^{a}$ & $(1.0)$ & $2.4^{\mathrm{d}}$ & $(0.3)$ & $5.9^{a}$ & $(0.4)$ \\
\hline & qPCR & $37.1^{b}$ & (2.8) & $12.2^{\mathrm{a}}$ & (1.8) & $1.6^{\mathrm{ef}}$ & $(0.2)$ & $4.3^{c}$ & $(0.2)$ \\
\hline & qPCRPMA & $32.4^{c}$ & $(1.4)$ & $10.1^{a}$ & $(1.5)$ & $2.0^{\text {de }}$ & $(0.2)$ & $4.4^{\mathrm{C}}$ & (0.3) \\
\hline
\end{tabular}

Values in the same column followed by different letters differ significantly (Newman-Keuls. $p<0.05$ ); * mean of 3 values (strain L120r); ${ }^{\dagger}$ detected but not quantified.

Considering the viable cells, the proportion of VBNC cells at T0 varied between the strains but was significantly higher $(p<0.05)$ in manures $(81.5-94.8 \%)$ than in lagoon effluents (67.8-79.2\%; Table 3). Their proportion changed over time. The biggest difference in the proportion of VBNC between T0 and T63 was observed in lagoon effluents at $20^{\circ} \mathrm{C}(18-21 \%)$ and the smallest in raw manures at $8^{\circ} \mathrm{C}(0.5-3.5 \%)$, suggesting that L. monocytogenes kinetics of entry into the VBNC state depended on the matrix and on the temperature.

In all the microcosms, quantification by qPCR gave similar results as by $\mathrm{qPCR}_{\mathrm{PMA}}$, indicating that the bacteria remained viable in both manure and lagoon effluent microcosms. The concomitant decline in total and viable bacteria suggests that the DNA of dead bacteria was rapidly degraded or bound to the matrix, thereby preventing its amplification. To test this hypothesis, a complementary experiment was performed. A culture of $L$. monocytogenes washed with sodium chloride and exposed to ultrasound ( $8 \mathrm{~min}, 360 \mathrm{~W}$ ) was placed in a water bath for $10 \mathrm{~min}$ at $85^{\circ} \mathrm{C}$ to damage the bacterial membrane. Manure and lagoon effluent were inoculated in triplicate with dead bacteria at an initial concentration of $710^{7} \mathrm{cfu} \mathrm{mL}^{-1}$. The manure and lagoon effluent were then incubated at $20^{\circ} \mathrm{C}$. The cell numbers measured by qPCR dropped by more than $3.2 \log _{10}$ within 5 days, confirming the rapid degradation of the DNA of dead bacteria in both the manure and lagoon effluent.

The conditions of each microcosm led to a particular behavior of the culturable and VBNC cells, suggesting that the persistence of $L$. monocytogenes was affected by the combined influence of the temperature and of the composition of the matrix.

\section{Chemical and Microbial Composition of the Manures and Lagoon Effluents}

The chemical composition of the four matrices differed but remained stable over the course of the experiment
(Supplementary Table S2) and was not affected by the incubation temperature. The $\mathrm{pH}$ ranged between 7.3 and 7.8 in the manures and between 8.0 and 9.0 in the lagoon effluent. Organic matter and nitrogen contents measured in manures ranged between 5.4 and $18.6 \mathrm{~g} \mathrm{~kg}^{-1}$ and between 1.8 and $4 \mathrm{gN} \mathrm{kg}^{-1}$, respectively, and were 10 -fold higher than in lagoon effluents. The level of total bacteria estimated by qPCR $_{\text {PMA }}$ was also 10 -fold higher in the manures than in lagoon effluents. At T0, they ranged from 9.3 to $9.8 \log _{10} \mathrm{cfu}$-eq $\mathrm{mL}^{-1}$ in the manures and from 8.4 to 8.7 $\log _{10}$ cfu-eq $\mathrm{mL}^{-1}$ in the lagoon effluents and did not change throughout the incubation period.

Since the behavior of the two strains was similar, the bacterial community profiles at T0 and T63 were assessed by 16S rRNA pyrosequencing of the microcosms inoculated with strain L111r. The observed OTU numbers and richness estimators (Chao 1 and ACE), showed that the richness values varied four and sevenfold among the microcosms, respectively (Table 4). The richness of the manure (4428-5470 observed OTUs) and the species diversity estimated by the Shannon index (8.2-9.3) decreased slightly during incubation. The richness of the lagoon effluent microcosms was more variable, ranging from 1388 to 4540 OTUs. The lowest diversity was observed in Lagoon- 1 at $8^{\circ} \mathrm{C}$, which also displayed the lowest richness. In contrast to the manure, the diversity of Lagoon- 2 increased at $8^{\circ} \mathrm{C}$ in the microcosms, or remained stable throughout incubation.

The relative taxonomic abundance of the bacterial community at the phylum level is presented in Figure 3 and Supplementary Table S3. Samples were dominated by four major phyla found in both manure and lagoon microcosms: Proteobacteria (7-26\% in manures; $10.5-83 \%$ in lagoons), Firmicutes (39-66\% in manures; $10-72.5 \%$ in lagoons), Bacteroidetes $(16-23 \%$ in manures; $1.8-22 \%$ in lagoons) and Actinobacteria (1.4-6.4\% in manures; $0.4-16 \%$ in lagoons). The relative abundance of the dominant phyla was more stable in manures than in lagoon effluents which varied between the two incubation temperatures. 


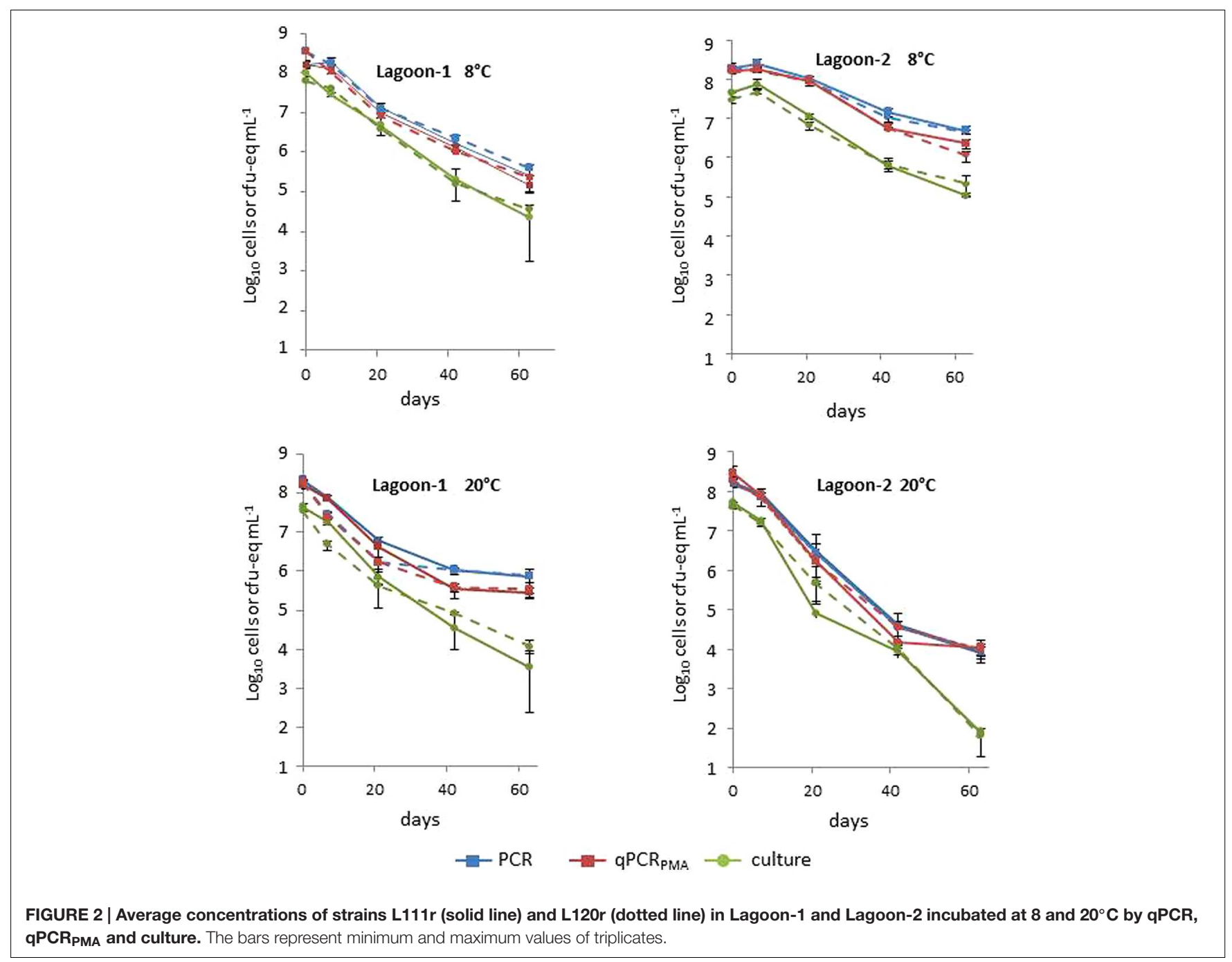

PCoA of the unweighted Unifrac distance (Figure 4) revealed significant differences between the $\beta$ diversity of the manure and lagoon microcosms. The manures clustered close together, showing that their bacterial communities remained stable over time regardless of temperature, whereas the lagoon effluents were more separated. At $8^{\circ} \mathrm{C}$, the overall composition of the microbiota in both lagoons was relatively stable, whereas changes in the communities occurred at $20^{\circ} \mathrm{C}$. Given the stability of the bacterial communities in the manures, it appears difficult to establish a link between the behavior of the strains and the relative taxonomic abundances of the bacterial community of the matrices. However, the $\log _{10}$ reduction in the number of viable cells of $L$. monocytogenes strain L111r estimated by qPCR PMA increased with an increase in species diversity and in the number of observed OTUs (Figure 5).

\section{DISCUSSION}

Little information is available on the survival and the ability of L. monocytogenes to enter in the VBNC state during
TABLE 3 | Percentage of VBNC cells among viable cells in the two strains of $L$. monocytogenes (mean of 6 values) at 8 and at $20^{\circ} \mathrm{C}$ in manure and lagoon effluent microcosms at T0 and T63 days.

\begin{tabular}{lllllll}
\hline \multirow{2}{*}{ Temperature $\left({ }^{\circ} \mathbf{C}\right)$} & Matrix & \multicolumn{3}{c}{ T0 } & & \multicolumn{2}{c}{ T63 } \\
\cline { 3 - 4 } \cline { 6 - 7 } & & Mean & (SD) & & Mean & (SD) \\
\hline 8 & Manure-1 & $94.5^{\mathrm{a}}$ & $(1.9)$ & & $95.0^{\mathrm{a}}$ & $(2.1)$ \\
8 & Manure-2 & $81.5^{\mathrm{b}}$ & $(5.9)$ & & $85.0^{\mathrm{b}}$ & $(6.3)$ \\
20 & Manure-1 & $94.8^{\mathrm{a}}$ & $(2.2)$ & & $98.8^{\mathrm{a}}$ & $(0.9)$ \\
20 & Manure-2 & $84.8^{\mathrm{ab}}$ & $(5.9)$ & & $99.8^{\mathrm{a}}$ & $(0.2)$ \\
& & & & & \\
8 & Lagoon-1 & $67.8^{\mathrm{c}}$ & $(17.2)$ & & $83.1^{\mathrm{b}}$ & $(2.6)$ \\
8 & Lagoon-2 & $76.1^{\mathrm{bc}}$ & $(5.4)$ & & $88.7^{\mathrm{b}}$ & $(8.3)$ \\
20 & Lagoon-1 & $79.2^{\mathrm{bc}}$ & $(4.6)$ & & $97.3^{\mathrm{a}}$ & $(3.0)$ \\
20 & Lagoon-2 & $78.1^{\mathrm{bc}}$ & $(5.0)$ & & $99.2^{\mathrm{a}}$ & $(0.7)$ \\
\hline
\end{tabular}

Values in the same column followed by different letters differ significantly (NewmanKeuls. $p<0.05$ ).

storage of the manure. In this study, the persistence of two strains of L. monocytogenes originating from piggery effluents 
TABLE 4 | Operational taxonomic units (OTU), Chao 1 (species richness estimator), ACE (abundance-based coverage estimator), and Shannon (diversity index) of samples calculated at T0 and after 63 days of incubation for each microcosm inoculated with strain L111r.

\begin{tabular}{|c|c|c|c|c|c|c|}
\hline Matrix & Temperature $\left({ }^{\circ} \mathrm{C}\right)$ & Time (days) & Observed OTUs & Chao1 & ACE & Shannon \\
\hline \multirow[t]{4}{*}{ Manure-1 } & 8 & 0 & 5470 & 19965 & 23270 & 9.5 \\
\hline & 8 & 63 & 5171 & 18536 & 21308 & 8.2 \\
\hline & 20 & 0 & 5280 & 12371 & 15136 & 8.3 \\
\hline & 20 & 63 & 4750 & 13233 & 15987 & 9.0 \\
\hline \multirow[t]{4}{*}{ Manure-2 } & 8 & 0 & 4872 & 15451 & 17821 & 8.9 \\
\hline & 8 & 63 & 4428 & 14046 & 16234 & 8.5 \\
\hline & 20 & 0 & 4962 & 15625 & 17912 & 9.0 \\
\hline & 20 & 63 & 4434 & 14431 & 16490 & 8.6 \\
\hline \multirow[t]{4}{*}{ Lagoon-1 } & 8 & 0 & 1388 & 3090 & 3329 & 4.3 \\
\hline & 8 & 63 & 2007 & 5231 & 5272 & 8.0 \\
\hline & 20 & 0 & 2659 & 6945 & 7842 & 6.5 \\
\hline & 20 & 63 & 2975 & 7780 & 8810 & 7.4 \\
\hline \multirow[t]{4}{*}{ Lagoon-2 } & 8 & 0 & 4540 & 14744 & 16621 & 8.5 \\
\hline & 8 & 63 & 4157 & 13731 & 15194 & 8.5 \\
\hline & 20 & 0 & 1989 & 5198 & 5505 & 6.6 \\
\hline & 20 & 63 & 3676 & 10293 & 11608 & 8.3 \\
\hline
\end{tabular}

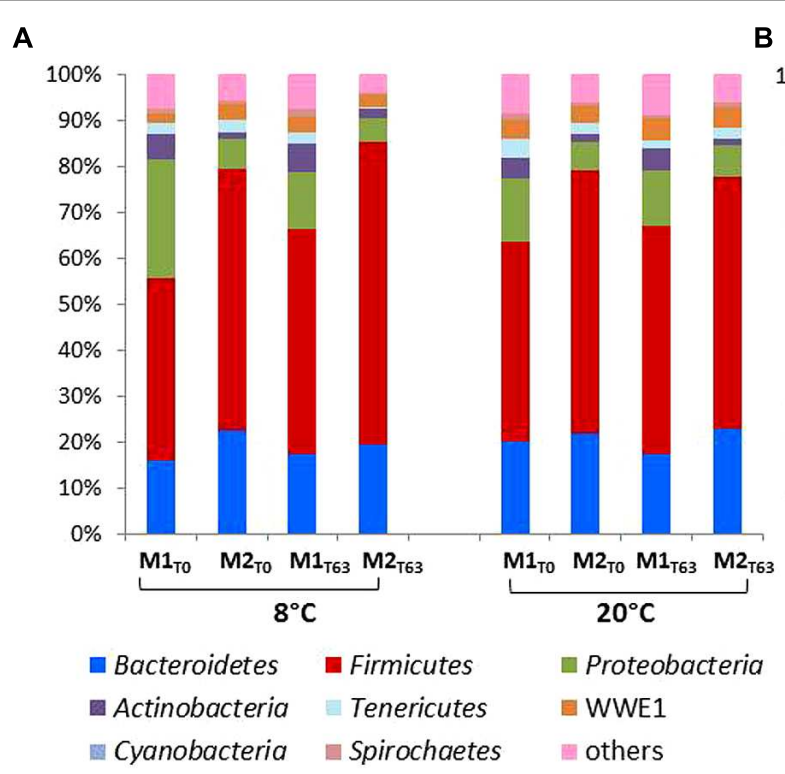

B

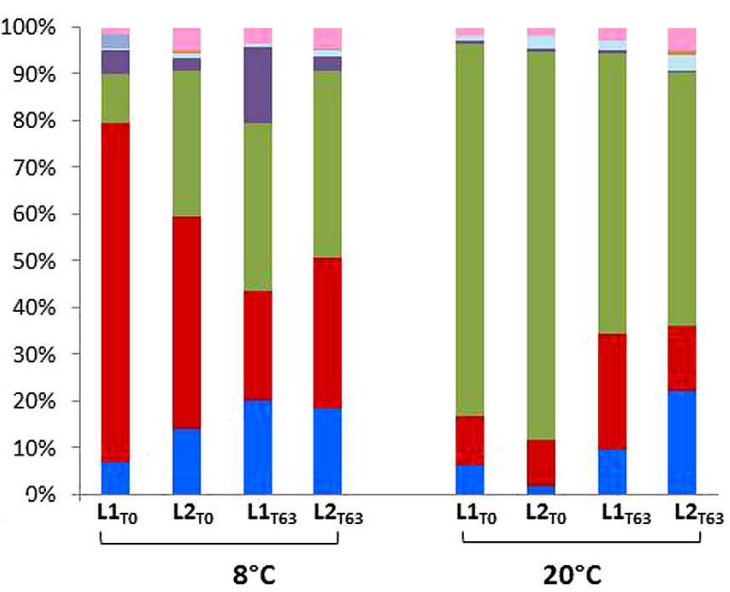

FIGURE 3 | Relative abundances of major phyla in manures (A) and lagoon effluents (B) microcosms at days T0 and T63. Only relative abundances of phylum higher than $1 \%$ are shown, all other sequences are included in "others."

was studied in raw manure and in lagoon effluent (liquid fraction of biologically treated manure) to see if storing the effluents favors the formation of VBNC cells. Both strains were still detected after 63 days of incubation regardless of the conditions of the microcosm, indicating a high potential for the persistence of $L$. monocytogenes in manures and their liquid fraction after biological treatment. The inactivation rates did not depend on the origin of the strain (manure or lagoon effluent) or of their serogroup (IIb, IVb). A similar trend has been observed in digested sludge inoculated at $35^{\circ} \mathrm{C}$ with other pathogens. Three strains of Salmonella and three strains of Escherichia coli underwent similar decay over an incubation period lasting 20 days, irrespective of the origin of the strain (Smith et al., 2005). Similarly, Garrec et al. (2005) found no difference in survival between two strains of $L$. monocytogenes inoculated in sewage sludge stored at $20^{\circ} \mathrm{C}$ for 70 days. However, McLaughlin et al. (2011) observed different behaviors of three strains of L. monocytogenes belonging to three serogroups 


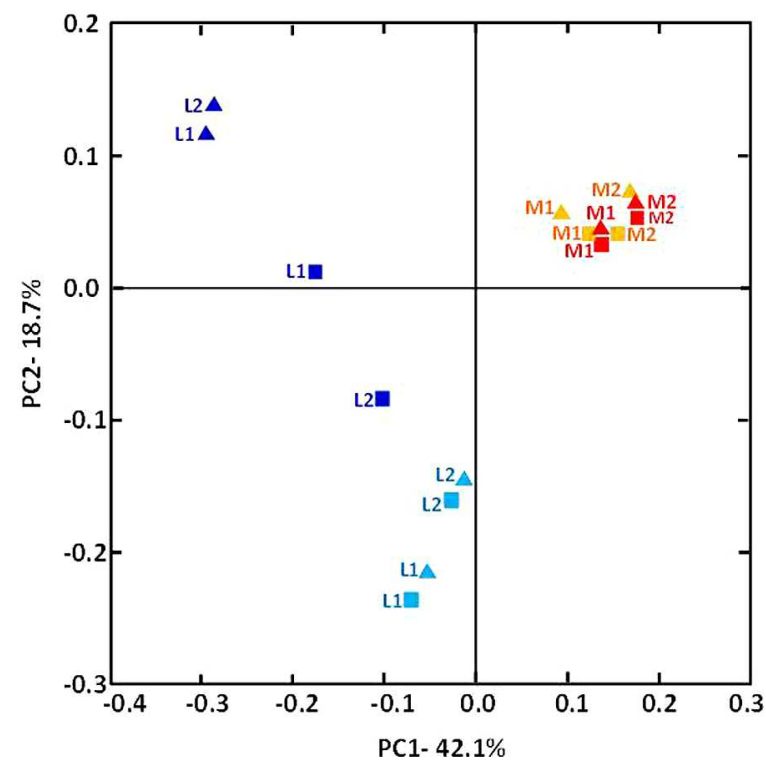

FIGURE 4 | $\beta$-diversity analysis of the composition of the manures and lagoon effluents inoculated with strain L111r. The phylogenetic dataset was analyzed using Jackknifed PCOA of the weighted pairwise UniFrac distance. Manure-1 (M1) and Manure-2 (M2) at $8^{\circ} \mathrm{C}$ (orange), M1 and M2 at $20^{\circ} \mathrm{C}$ (red), lagoon-1 (L1), and lagoon-2 (L2) at $8^{\circ} \mathrm{C}$ (pale blue), L1 and L2 at $20^{\circ} \mathrm{C}$ (dark blue); triangles represent T0; squares represent T63.

inoculated in a soil stored at $25^{\circ} \mathrm{C}$ or at $30^{\circ} \mathrm{C}$ for 6 days, suggesting that, depending on the type of matrix inoculated, the intrinsic characteristics of the strains may have an effect. It is known that the persistence of pathogenic bacteria in the environment depends on biotic and abiotic parameters and on their interaction. In our study, the properties of the matrices appeared to mainly impact the survival of the two strains.

\section{Effect of the Matrix}

Although the lagoon effluent microcosms allowed air to penetrate and the concentrations of VS and nitrogen in these matrices were 10 times lower than in the raw manures, no clear difference in the survival rate was observed between these two types of effluents. At $8^{\circ} \mathrm{C}$, the survival of culturable and viable $L$. monocytogenes differed with the origin of the effluent (farm 1 or farm 2) rather than between raw and treated manures. The T90 values were lower in the effluents collected from farm 1 than in the effluents from the farm 2 . At $20^{\circ} \mathrm{C}$, except for the T90 value observed in Manure-1, which was significantly lower than that observed in the three other matrices, the differences in the behavior of the strains between the effluents from the two farms were less marked. Since the chemical and microbial parameters of the manures were similar, there is no apparent explanation for the particular biphasic decay of cultivable L. monocytogenes observed in Manure- 1 at $20^{\circ} \mathrm{C}$.

The effect of the matrix on the survival of L. monocytogenes has also been investigated in different types of matrices. Lemunier et al. (2005) and Paniel et al. (2010) observed that the persistence of L. monocytogenes in composts depended on the degree of
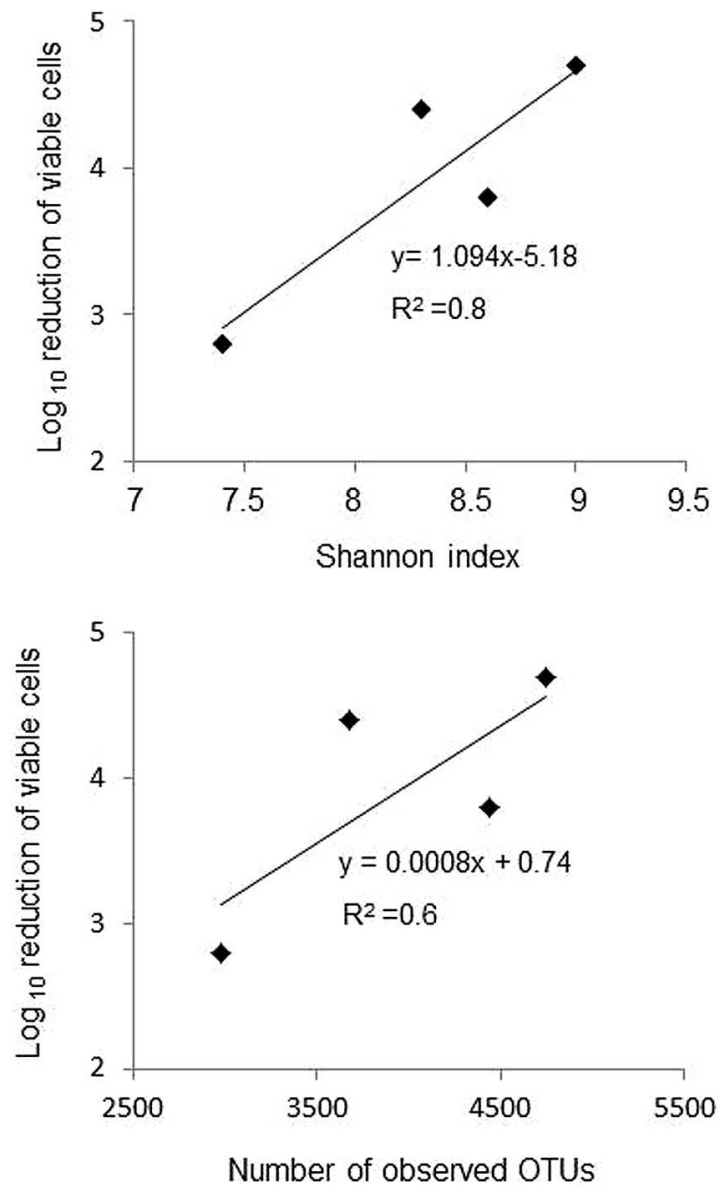

FIGURE 5 | Relationship between $\log _{10}$ reduction of viable cells of strain L111r estimated by $\mathrm{PPCR}_{\mathrm{PMA}}$ incubated at $20^{\circ} \mathrm{C}$ and the Shannon index and the numbers of observed OTUs at T63.

maturation of the inoculated matrices. Likewise, Klein et al. (2011) reported T90 values for L. monocytogenes (determined using the cultural method) of 11 days in stockpiled manure and 17 days in composted manure maintained at $20^{\circ} \mathrm{C}$. Our results highlight the combined effect of the matrix and the temperature on the survival of L. monocytogenes, which has also been observed in soil and in manured soil inoculated with a strain of Salmonella Typhimurium (Garcia et al., 2010). In that case, the presence of manure in the soil significantly reduced the survival of the strain of Salmonella at $5^{\circ} \mathrm{C}$ and $15^{\circ} \mathrm{C}$ but not at $25^{\circ} \mathrm{C}$. Furthermore, characteristics of manure matrix can also contribute to the survival of pathogens as suggested by Diao et al. (2015) who observed that temperature, moisture content and particle size of dairy compost affected the survival of E. coli O157:H7 and Salmonella Typhimurium.

\section{Effect of Temperature}

As expected, the lowest temperature increased the survival of L. monocytogenes. The effect of temperature on the persistence of pathogenic or enteric bacteria is well known and has been reported for Salmonella, Campylobacter coli, L. monocytogenes, 
and E.coli in livestock waste, in manure, and in manured soil (Mawdsley et al., 1995; Himathongkham et al., 1999; Arrus et al., 2006; Semenov et al., 2007; Garcia et al., 2010; Bui et al., 2011; Klein et al., 2011). In bovine manure-amended soil, Jiang et al. (2004) detected L. monocytogenes up to 43 days at $5^{\circ} \mathrm{C}$, and up to 21 days $21^{\circ} \mathrm{C}$. However, in our study, the impact of the temperature varied with the matrix. Indeed, the difference in $\log _{10}$ reduction for a given matrix after 63 days of incubation at between 8 and $20^{\circ} \mathrm{C}$ ranged from $0.4 \log _{10}$ (Lagoon-1) to 5 $\log _{10}$ (Manure-2). This is consistent with the results reported by Klein et al. (2011), who compared the behavior of an inoculated strain of L. monocytogenes in microcosms containing stockpiled or composted manure. After 10 days of incubation, the $\log _{10}$ reduction in composted manure decreased by 4 at $37^{\circ} \mathrm{C}$ and by 1.5 at $20^{\circ} \mathrm{C}$, and in stockpiled manure, it decreased by 3.5 at $37^{\circ} \mathrm{C}$ and by 2 at $20^{\circ} \mathrm{C}$.

\section{Effect of Autochthonous Flora}

After the manures and lagoon effluents were acclimatized at the two temperatures for 8 days, the composition of the autochthonous flora in the manures was similar at 8 and $20^{\circ} \mathrm{C}$, but differed in the lagoon effluents. The three major OTUs (Firmicutes, Bacteroidetes, and Proteobacteria) found in the two farm effluents were also dominant in the surface crust of swine slurry (Duan et al., 2014). Lu et al. (2014) also reported a high proportion of Firmicutes and Bacteroidetes in pig and piglet manures, whereas in their study Proteobacteria accounted for less than $1.5 \%$ of identified taxa. At T0, Firmicutes dominated in manures at both temperatures and in lagoon effluents at $8^{\circ} \mathrm{C}$. This phylum was less abundant in lagoon effluents at $20^{\circ} \mathrm{C}$ in which Proteobacteria dominated. After 2 months of incubation, the relative abundance of the dominant phyla in the manures and the lagoon effluents remained relatively stable. The manures showed higher diversity than the lagoon effluents, indicating that the biological treatment and the subsequent storage of the liquid effluent reduced both richness and diversity. The behavior of L. monocytogenes (especially the low T90 value observed in Manure- 1 at $20^{\circ} \mathrm{C}$ ) does not appear to be influenced by the taxonomic composition of the manures and lagoon effluent communities. Nevertheless, interestingly, the decline in the number of viable cells of strain L111r increased with an increase in species diversity and in the number of OTUs. This finding is in agreement with the results of a study by Vivant et al. (2013), who reported that the survival of L. monocytogenes in soil microcosms decreased with the diversity and abundance of bacterial communities.

\section{Formation of VBNC in Manure and Lagoon Effluent}

The persistence of Listeria in environmental matrices (soil, whether manured or not, compost, manure) is mainly estimated by culture methods (Hutchison et al., 2005; Lemunier et al., 2005; Nicholson et al., 2005; Paniel et al., 2010; Piveteau et al., 2011; Locatelli et al., 2013; Vivant et al., 2013). Yet several studies on food products, biofilms, and water, showed that $L$. monocytogenes can enter the VBNC state (Besnard et al., 2000, 2002). Moreover, the presence of a VBNC indicator or of pathogenic bacteria in sludge has been suggested by comparing the results of culture and qPCR methods (Higgins et al., 2007; Viau and Peccia, 2009; Erkan and Sanin, 2013). But only a few studies have demonstrated the presence of indicator or pathogenic bacteria in the VBNC state in sludge or in manured soil using PMA or RNA based techniques (Jiang et al., 2013; Fu et al., 2014). Although the use of qPCR $\mathrm{PMA}$ to detect viable bacteria in sludge is limited by problems with turbid matrices (Wagner et al., 2008), we previously demonstrated that qPCR $\mathrm{PMA}$ can be applied to manures after optimisation of the conditions of exposure (Desneux et al., 2015). In the present study, analysis of cell viability in the microcosms, conducted using PMA, showed that L. monocytogenes entered the VBNC state in piggery effluents. The number of VBNC cells in broth before inoculation was not estimated. However, although the strains were inoculated in similar condition in all experiments (early stationary-phase cells), different proportions of VBNC cells among viable cells were observed at T0 (ranged from 68 to $79 \%$ in lagoons and from 81.5 to $95 \%$ in manures). These results suggested that the loss of culturability depended on the type of matrix in the first hour of contact. The rapid appearance of VBNC cells we observed in the microcosms is in agreement with the work of Piveteau et al. (2011), who used whole-genome microarrays to analyze transcriptome modifications in a soil extract inoculated with a strain of $L$. monocytogenes. Their analysis revealed massive transcriptional modifications within 30 min of incubation. In our study, although viable bacteria decreased over time in all the microcosms, the proportion of VBNC increased. The kinetic of appearance of VBNC cells depended on the matrices. Manures appeared to be more favorable to a switch in L. monocytogenes cells to VBNC than lagoon effluents within the first hours of contact whereas after 63 days of incubation, the proportion of VBNC was similar in the two types of matrix. Furthermore, the proportion of $\mathrm{VBNC}$ was higher at $20^{\circ} \mathrm{C}$ than at $8^{\circ} \mathrm{C}$. This may reflect the greater ability of this psychrophilic bacterium to survive and to maintain culturability at low temperatures. It is noteworthy that culturability also depends on the physiological state of the inoculated bacteria. Thus, we observed that when L. monocytogenes cells in the exponential phase were used as the inoculum for the microcosms instead of stationary cells, the proportion of VBNC at T0 decreased by $14 \%$ (data not shown).

The comparison of quantification of viable and total L. monocytogenes cells by $\mathrm{qPCR}_{\mathrm{PMA}}$ and $\mathrm{qPCR}$ clearly showed that extracellular DNA was rapidly degraded in these environments, providing an additional source of nutrients. The rapid disappearance of DNA we observed at $20^{\circ} \mathrm{C}$ is supported by data in the literature, which also showed a high recycling rate of extracellular DNA in manure (Lebuhn et al., 2004; Klein et al., 2011).

\section{CONCLUSION}

This study showed that the survival of L. monocytogenes, which was shorter at $20^{\circ} \mathrm{C}$ than at $8^{\circ} \mathrm{C}$, did not depend on the serotype 
or on the origin of the strain. Although lagoon effluents were less concentrated than manures, this did not impair the survival of L. monocytogenes. Here, for the first time, we demonstrate the ability of L. monocytogenes to become VBNC in manures and to persist in this state for at least 2 months. The high proportion of VBNC, which increased over time and reached $99.8 \%$ of viable bacteria, confirmed that the culture method currently used to detect pathogens in manured material results in underestimation of the survival rate of pathogens during storage of manure. The PMA based method appears as a promising approach to assess the potential health risk associated with manure handling.

\section{AUTHOR CONTRIBUTIONS}

JD and A-MP designed laboratory work. JD performed microbiology laboratory work, as well as drafting the manuscript. A-MP finalized the manuscript. SP performed the chemical

\section{REFERENCES}

Adela Yanez, M., Nocker, A., Soria-Soria, E., Murtula, R., Martinez, L., and Catalan, V. (2011). Quantification of viable Legionella pneumophila cells using propidium monoazide combined with quantitative PCR. J. Microbiol. Methods 85, 124-130. doi: 10.1016/j.mimet.2011.02.004

APHA (1998). Standards Methods for the Examination of Water and Wastewater, 20th Edn. Washington, DC: American Public Heath Association.

Arrus, K. M., Holley, R. A., Ominski, K. H., Tenuta, M., and Blank, G. (2006). Influence of temperature on Salmonella survival in hog manure slurry and seasonal temperature profiles in farm manure storage reservoirs. Livestock Sci. 102, 226-236. doi: 10.1016/j.livsci.2006.03.021

Besnard, V., Federighi, M., and Cappelier, J. M. (2000). Evidence of viable but non-culturable state in Listeria monocytogenes by direct viable count and CTC-DAPI double staining. Food Microbiol. 17, 697-704. doi: 10.1006/fmic. 2000.0366

Besnard, V., Federighi, M., Declerq, E., Jugiau, F., and Cappelier, J. M. (2002). Environmental and physico-chemical factors induce VBNC state in Listeria monocytogenes. Vet Res. 33, 359-370. doi: 10.1051/vetres:2002022

Boscher, E., Houard, E., and Denis, M. (2012). Prevalence and distribution of Listeria monocytogenes serotypes and pulsotypes in sows and fattening pigs in farrow-to-finish farms (France, 2008). J. Food Prot. 75, 889-895. doi: 10.4315/0362-028x.jfp-11-340

Bui, X. T., Wolff, A., Madsen, M., and Bang, D. D. (2011). Fate and survival of Campylobacter coli in swine manure at various temperatures. Front. Microbiol. 2:262. doi: $10.3389 /$ fmicb.2011.00262

Caporaso, J. G., Bittinger, K., Bushman, F. D., DeSantis, T. Z., Andersen, G. L., and Knight, R. (2010a). PyNAST: a flexible tool for aligning sequences to a template alignment. Bioinformatics. 26, 266-267. doi: 10.1093/bioinformatics/btp636

Caporaso, J. G., Kuczynski, J., Stombaugh, J., Bittinger, K., Bushman, F. D., Costello, E. K., et al. (2010b). QIIME allows analysis of highthroughput community sequencing data. Nat. Methods 7, 335-336. doi: 10.1038/nmeth.f.303

Cappelier, J. M., Besnard, V., Roche, S. M., Velge, P., and Federighi, M. (2007). Avirulent viable but non culturable cells of Listeria monocytogenes need the presence of an embryo to be recovered in egg yolk and regain virulence after recovery. Vet Res. 38, 573-583. doi: 10.1051/vetres:2007017

Contreras, P. J., Urrutia, H., Sossa, K., and Nocker, A. (2011). Effect of PCR amplicon length on suppressing signals from membrane-compromised cells by propidium monoazide treatment. J. Microbiol. Methods 87, 89-95. doi: 10.1016/j.mimet.2011.07.016

Desneux, J., Chemaly, M., and Pourcher, A. M. (2015). Experimental design for the optimization of propidium monoazide treatment to quantify viable and non-viable bacteria in piggery effluents. BMC Microbiol. 15:164. doi: 10.1186/s12866-015-0505-6 analyses. $\mathrm{AB}$ participated to a part of the microbiology laboratory work. All authors read and approved the final manuscript.

\section{ACKNOWLEDGMENTS}

This work was supported by the French Agency for Food, Environmental and Occupational Health and Safety (ANSES) and by the French Environment and Energy Management Agency (ADEME). JD is recipient of an Irstea-Région Bretagne fellowship.

\section{SUPPLEMENTARY MATERIAL}

The Supplementary Material for this article can be found online at: http://journal.frontiersin.org/article/10.3389/fmicb. 2016.00245

Desneux, J., and Pourcher, A.-M. (2014). Comparison of DNA extraction kits and modification of DNA elution procedure for the quantitation of subdominant bacteria from piggery effluents with real-time PCR. Microbiology 3, 437-445. doi: $10.1002 / \mathrm{mbo} .178$

Diao, J., Chen, Z., Gong, C., and Jiang, X. (2015). Factors affecting pathogen survival in finished dairy compost with different particle sizes under greenhouse conditions. Foodborne Pathog. Dis. 12, 749-758. doi: 10.1089/fpd.2014.1912

Dong, S., Hong, P.-Y., and Nguyen, T. (2014). Persistence of Bacteroides ovatus under simulated sunlight irradiation. BMC Microbiol. 14:178. doi: 10.1186/1471-2180-14-178

Duan, Y. F., Al-Soud, W. A., Brejnrod, A., Sorensen, S. J., Elsgaard, L., Petersen, S. O., et al. (2014). Methanotrophs, methanogens and microbial community structure in livestock slurry surface crusts. J. Appl. Microbiol. 117, 1066-1078. doi: $10.1111 /$ jam.12584

Dungan, R. S., Klein, M., and Leytem, A. B. (2012). Quantification of bacterial indicators and zoonotic pathogens in dairy wastewater ponds. Appl. Environ. Microbiol. 78, 8089-8095. doi: 10.1128/aem.02470-12

Edgar, R. C. (2010). Search and clustering orders of magnitude faster than BLAST. Bioinformatics. 26, 2460-2461. doi: 10.1093/bioinformatics/btq461

Erickson, M. C., Liao, J., Ma, L., Jiang, X., and Doyle, M. P. (2014). Thermal and nonthermal factors affecting survival of salmonella and Listeria monocytogenes in animal manure-based compost mixtures. J. Food Prot. 77, 1512-1518. doi: 10.4315/0362-028x.jfp-14-111

Erkan, M., and Sanin, F. D. (2013). Can sludge dewatering reactivate microorganisms in mesophilically digested anaerobic sludge? Case of belt filter versus centrifuge. Water Res. 47, 428-438. doi: 10.1016/j.watres.2012.10.028

Farzan, A., Friendship, R. M., Dewey, C. E., Poppe, C., and Funk, J. (2010). Evaluation of the risk factors for shedding salmonella with or without antimicrobial resistance in swine using multinomial regression method. Zoonoses Public Health 57, 85-93. doi: 10.1111/j.1863-2378.2010.01357.x

Forghani, F., Langaee, T., Eskandari, M., Seo, K.-H., Chung, M.-J., and Oh, D.-H. (2015). Rapid detection of viable Bacillus cereus emetic and enterotoxic strains in food by coupling propidium monoazide and multiplex PCR (PMA-mPCR). Food Control 55, 151-157. doi: 10.1016/j.foodcont.2015.02.049

Fu, B., Jiang, Q., Liu, H., and Liu, H. (2014). Occurrence and reactivation of viable but non-culturable $E$. coli in sewage sludge after mesophilic and thermophilic anaerobic digestion. Biotechnol. Lett. 36, 273-279. doi: 10.1007/s10529-0131361-9

Gandhi, M., and Chikindas, M. L. (2007). Listeria: a foodborne pathogen that knows how to survive. Int. J. Food Microbiol. 113, 1-15. doi: 10.1016/j.ijfoodmicro.2006.07.008

Garcia, R., Baelum, J., Fredslund, L., Santorum, P., and Jacobsen, C. S. (2010). Influence of temperature and predation on survival of Salmonella enterica serovar typhimurium and expression of inva in soil and manure-amended soil. Appl. Environ. Microbiol. 76, 5025-5031. doi: 10.1128/aem.00628-10 
Garrec, N., Besnard, V., Magras, C., Pourcher, A. M., and Federighi, M. (2005). Behaviour of Listeria monocytogenes scott a and a wild strain in different sewage sludge matrices : evaluation of culturability and viability and determination of potential virulence in a mice bioassay. Rev. Med. Vet. 156, 148-154.

Goberna, M., Podmirseg, S. M., Waldhuber, S., Knapp, B. A., Garcia, C., and Insam, H. (2011). Pathogenic bacteria and mineral $\mathrm{N}$ in soils following the land spreading of biogas digestates and fresh manure. Appl. Soil Ecol. 49, 18-25. doi: 10.1016/j.apsoil.2011.07.007

Godon, J. J., Zumstein, E., Dabert, P., Habouzit, F., and Moletta, R. (1997). Molecular microbial diversity of an anaerobic digestor as determined by smallsubunit rDNA sequence analysis. Appl. Environ. Microbiol. 63, 2802-2813.

Grewal, S., Sreevatsan, S., and Michel, F. C. Jr. (2007). Persistence of Listeria and Salmonella during swine manure treatment. Compost Sci. Util. 15, 53-62. doi: 10.1080/1065657X.2007.10702311

Guan, T. Y., and Holley, R. A. (2003). Pathogen survival in swine manure environments and transmission of human enteric illness: a review. J. Environ. Qual. 32, 383-392. doi: 10.2134/jeq2003.3830

Hellstrom, S., Laukkanen, R., Siekkinen, K.-M., Ranta, J., Maijala, R., and Korkeala, H. (2010). Listeria monocytogenes contamination in pork can originate from farms. J. Food Prot. 73, 641-648.

Higgins, M. J., Chen, Y.-C., Murthy, S. N., Hendrickson, D., Farrel, J., and Schafer, P. (2007). Reactivation and growth of non-culturable indicator bacteria in anaerobically digested biosolids after centrifuge dewatering. Water Res. 41, 665-673. doi: 10.1016/j.watres.2006.09.017

Himathongkham, S., Bahari, S., Riemann, H., and Cliver, D. (1999). Survival of Escherichia coli $\mathrm{O} 157$ : H7 and Salmonella Typhimurium in cow manure and cow manure slurry. FEMS Microbiol. Lett. 178, 251-257. doi: 10.1111/j.15746968.1999.tb08684.x

Hutchison, M. L., Walters, L. D., Avery, S. M., and Moore, A. (2005). Decline of zoonotic agents in livestock waste and bedding heaps. J. Appl. Microbiol. 99, 354-362. doi: 10.1111/j.1365-2672.2005.02591.x

Jiang, Q., Fu, B., Chen, Y., Wang, Y., and Liu, H. (2013). Quantification of viable but nonculturable bacterial pathogens in anaerobic digested sludge. Appl. Microbiol. Biotechnol. 97, 6043-6050. doi: 10.1007/s00253-012-4408-2

Jiang, X. P., Islam, M., Morgan, J., and Doyle, M. P. (2004). Fate of Listeria monocytogenes in bovine manure-amended soil. J. Food Prot. 67, 1676-1681.

Klein, M., Brown, L., Ashbolt, N. J., Stuetz, R. M., and Roser, D. J. (2011). Inactivation of indicators and pathogens in cattle feedlot manures and compost as determined by molecular and culture assays. FEMS Microbiol. Ecol. 77, 200-210. doi: 10.1111/j.1574-6941.2011.01098.x

Lebuhn, M., Effenberger, M., Garces, G., Gronauer, A., and Wilderer, P. A. (2004). Evaluating real-time PCR for the quantification of distinct pathogens and indicator organisms in environmental samples. Water Sci. Technol. 50, 263-270.

Lemunier, M., Francou, C., Rousseaux, S., Houot, S., Dantigny, P., Piveteau, P., et al. (2005). Long-term survival of pathogenic and sanitation indicator bacteria in experimental biowaste composts. Appl. Environ. Microbiol. 71, 5779-5786. doi: 10.1128/aem.71.10.5779-5786.2005

Li, D., Tong, T., Zeng, S., Lin, Y., Wu, S., and He, M. (2014). Quantification of viable bacteria in wastewater treatment plants by using propidium monoazide combined with quantitative PCR (PMA-qPCR). J. Environ. Sci. (China) 26, 299-306. doi: 10.1016/s1001-0742(13)60425-8

Lindback, T., Rottenberg, M. E., Roche, S. M., and Rorvik, L. M. (2010). The ability to enter into an avirulent viable but non-culturable (VBNC) form is widespread among Listeria monocytogenes isolates from salmon, patients and environment. Vet. Res. 41, 8. doi: 10.1051/vetres/2009056

Locatelli, A., Spor, A., Jolivet, C., Piveteau, P., and Hartmann, A. (2013). Biotic and abiotic soil properties influence survival of Listeria monocytogenes in soil. PLoS ONE 8:e75969. doi: 10.1371/journal.pone.0075969

Lozupone, C., Hamady, M., and Knight, R. (2006). UniFrac - An online tool for comparing microbial community diversity in a phylogenetic context. BMC Bioinform. 7:371. doi: 10.1186/1471-2105-7-371

Lozupone, C., and Knight, R. (2005). UniFrac: a new phylogenetic method for comparing microbial communities. Appl. Environ. Microbiol. 71, 8228-8235. doi: 10.1128/aem.71.12.8228-8235.2005

Lozupone, C., Lladser, M. E., Knights, D., Stombaugh, J., and Knight, R. (2011). UniFrac: an effective distance metric for microbial community comparison. ISME J. 5, 169-172. doi: 10.1038/ismej.2010.133
Lu, X.-M., Lu, P.-Z., and Zhang, H. (2014). Bacterial communities in manures of piglets and adult pigs bred with different feeds revealed by $16 \mathrm{~S}$ rDNA 454 pyrosequencing. Appl. Microbiol. Biotechnol. 98, 2657-2665. doi: 10.1007/s00253-013-5211-4

Lung, A. J., Lin, C. M., Kim, J. M., Marshall, M. R., Nordstedt, R., Thompson, N. P., et al. (2001). Destruction of Escherichia coli O157 : H7 and Salmonella Enteritidis in cow manure composting. J. Food Prot. 64, 1309-1314.

Lyautey, E., Lapen, D. R., Wilkes, G., McCleary, K., Pagotto, F., Tyler, K., et al. (2007). Distribution and characteristics of Listeria monocytogenes isolates from surface waters of the South Nation River watershed, Ontario, Canada. Appl. Environ. Microbiol. 73, 5401-5410. doi: 10.1128/aem.00354-07

Mawdsley, J. L., Bardgett, R. D., Merry, R. J., Pain, B. F., and Theodorou, M. K. (1995). Pathogens in livestock waste, their potential for movement through soil and environmental pollution. Appl Soil Ecol. 2, 1-15. doi: 10.1016/09291393(94)00039-A

McLaughlin, H. P., Casey, P. G., Cotter, J., Gahan, C. G. M., and Hill, C. (2011). Factors affecting survival of Listeria monocytogenes and Listeria innocua in soil samples. Arch. Microbiol. 193, 775-785. doi: 10.1007/s00203-011-0716-7

Mengaud, J., Vicente, M. F., Chenevert, J., Pereira, J. M., Geoffroy, C., Gicquelsanzey, B., et al. (1988). Expression in Escherichia coli and sequenceanalysis of the listeriolysin-O determinant of Listeria monocytogenes. Infect. Immun. 56, 766-772.

Millner, P., Ingram, D., Mulbry, W., and Arikan, O. A. (2014). Pathogen reduction in minimally managed composting of bovine manure. Waste Manage. 34, 1992-1999. doi: 10.1016/j.wasman.2014.07.021

Mohammed, H. O., Atwill, E., Dunbar, L., Ward, T., McDonough, P., Gonzalez, R., et al. (2010). The risk of Listeria monocytogenes infection in beef cattle operations. J. Appl. Microbiol. 108, 349-356. doi: 10.1111/j.13652672.2009.04446.x

Nicholson, F. A., Groves, S. J., and Chambers, B. J. (2005). Pathogen survival during livestock manure storage and following land application. Bioresour. Technol. 96, 135-143. doi: 10.1016/j.biotech.2004.02.030

Nightingale, K. K., Schukken, Y. H., Nightingale, C. R., Fortes, E. D., Ho, A. J., Her, Z., et al. (2004). Ecology and transmission of Listeria monocytogenes infecting ruminants and in the farm environment. Appl. Environ. Microbiol. 70, 4458-4467. doi: 10.1128/aem.70.8.4458-4467.2004

Nocker, A., Cheung, C.-Y., and Camper, A. K. (2006). Comparison of propidium monoazide with ethidium monoazide for differentiation of live vs. dead bacteria by selective removal of DNA from dead cells. J. Microbiol. Methods. 67, 310-320. doi: 10.1016/j.mimet.2006.04.015

Nogva, H. K., Rudi, K., Naterstad, K., Holck, A., and Lillehaug, D. (2000). Application of $5^{\prime}$-nuclease PCR for quantitative detection of Listeria monocytogenes in pure cultures, water, skim milk, and unpasteurized whole milk. Appl. Environ. Microbiol. 66, 4266-4271. doi: 10.1128/aem.66.10.42664271.2000

Paniel, N., Rousseaux, S., Gourland, P., Poitrenaud, M., and Guzzo, J. (2010). Assessment of survival of Listeria monocytogenes, Salmonella Infantis and Enterococcus faecalis artificially inoculated into experimental waste or compost. J. Appl. Microbiol. 108, 1797-1809. doi: 10.1111/j.1365-2672.2009. 04584.x

Peu, P., Beline, F., and Martinez, J. (2004). Volatile fatty acids analysis from pig slurry using high-performance liquid chromatography. Int. J. Environ. Anal. Chem. 84, 1017-1022. doi: 10.1080/03067310412331303217

Piveteau, P., Depret, G., Pivato, B., Garmyn, D., and Hartmann, A. (2011). Changes in gene expression during adaptation of Listeria monocytogenes to the soil environment. PLoS ONE 6:e24881. doi: 10.1371/journal.pone.0024881

Pourcher, A. M., Ziebal, C., Kervarrec, M., Bioteau, T., and Dabert, P. (2012). Sanitary status of 44 hog manures in brittany: comparaison of the effectiveness of manure treatments based on the levels of indicator bacteria and two pathogenic bacteria. J. Agric. Sci. Technol. A 2, 303-313.

Roberts, A. J., and Wiedmann, M. (2003). Pathogen, host and environmental factors contributing to the pathogenesis of listeriosis. Cell Mol. Life. Sci. 60, 904-918. doi: 10.1007/s00018-003-2225-6

Schlech, W. F., Lavigne, P. M., Bortolussi, R. A., Allen, A. C., Haldane, E. V., Wort, A. J., et al. (1983). Epidemic listeriosis - Evidence for transmission by food. New Engl. J. Med. 308, 203-206. doi: 10.1056/nejm198301273080407

Semenov, A. V., van Bruggen, A. H. C., van Overbeek, L., Termorshuizen, A. J., and Semenov, A. M. (2007). Influence of temperature fluctuations on Escherichia coli 
O157 : H7 and Salmonella enterica serovar Typhimurium in cow manure. FEMS Microbiol. Ecol. 60, 419-428. doi: 10.1111/j.1574-6941.2007.00306.x

Smith, S. R., Lang, N. L., Cheung, K. H. M., and Spanoudaki, K. (2005). Factors controlling pathogen destruction during anaerobic digestion of biowastes. Waste Manage. 25, 417-425. doi: 10.1016/j.wasman.2005.02.010

Stea, E. C., Purdue, L. M., Jamieson, R. C., Yost, C. K., and Hansen, L. T. (2015). Comparison of the prevalences and diversities of Listeria Species and Listeria monocytogenes in an Urban and a Rural Agricultural Watershed. Appl. Environ. Microbiol. 81, 3812-3822. doi: 10.1128/aem.00416-15

Varma, M., Field, R., Stinson, M., Rukovets, B., Wymer, L., and Hauglanda, R. (2009). Quantitative real-time PCR analysis of total and propidium monoazideresistant fecal indicator bacteria in wastewater. Water Res. 43, 4790-4801. doi: 10.1016/j.watres.2009.05.031

Viau, E., and Peccia, J. (2009). Evaluation of the enterococci indicator in biosolids using culture-based and quantitative PCR assays. Water Res. 43, 4878-4887. doi: 10.1016/j.watres.2009.09.016

Vivant, A.-L., Garmyn, D., Maron, P.-A., Nowak, V., and Piveteau, P. (2013). Microbial diversity and structure are drivers of the biological barrier effect against Listeria monocytogenes in soil. PLoS ONE 8:e76991. doi: 10.1371/journal.pone.0076991

Wagner, A. O., Malin, C., Knapp, B. A., and Illmer, P. (2008). Removal of free extracellular DNA from environmental samples by ethidium monoazide and propidium monoazide. Appl. Environ. Microbiol. 74, 2537-2539. doi: 10.1128/aem.02288-07

Weisburg, W. G., Barns, S. M., Pelletier, D. A., and Lane, D. J. (1991). 16S ribosomal DNA amplification for phylogenetic study. J. Bacteriol. 173, 697-703.

Wery, N., Pourcher, A. M., Stan, V., Delgenes, J. P., Picard-Bonnaud, F., and Godon, J. J. (2006). Survival of Listeria monocytogenes and Enterococcus faecium in sludge evaluated by real-time PCR and culture methods. Lett. Appl. Microbiol. 43, 131-136. doi: 10.1111/j.1472-765X.2006.01946.x

Xiong, R., Xie, G., Edmondson, A. E., and Sheard, M. A. (1999). A mathematical model for bacterial inactivation. Int. J. Food Microbiol. 46, 45-55. doi: 10.1016/s0168-1605(98)00172-x

Conflict of Interest Statement: The authors declare that the research was conducted in the absence of any commercial or financial relationships that could be construed as a potential conflict of interest.

Copyright (C) 2016 Desneux, Biscuit, Picard and Pourcher. This is an open-access article distributed under the terms of the Creative Commons Attribution License (CC BY). The use, distribution or reproduction in other forums is permitted, provided the original author(s) or licensor are credited and that the original publication in this journal is cited, in accordance with accepted academic practice. No use, distribution or reproduction is permitted which does not comply with these terms. 